\title{
Susceptibility of pea, horse bean and bean to viruses in dependence on the age of the inoculated plants
}

\author{
WLADYSLAW BLASZCZAK, GRAŻYNA ELLMANN-WĄSIK, RENATA LESIAK-JERZYK \\ Department of Phytopathology, Agricultural University, ul. Dąbrowskiego 159, 60-534 Poznań, \\ Poland
}

(Received: June 21, 1983)

\begin{abstract}
Three cultivars of pea did not differ in their susceptibility to Cucumber Mosaic Virus (CMV) notwithstanding the age of the inoculated plants. But their susceptibility to infection with Bean Yellow Mosaic Virus (BYMV) differed. Horse bean cultivars 'Nadwiślański' and 'Major' proved to be less susceptible to Broad Bean True Mosaic Virus (BBTMV) when older plants were inoculated. Two bean cultivars 'Zlota Saxa' and 'Earle' appeared to be susceptible to BBTMV only in the phase of developing primary leaves and the age-dependent resistance to infection increased faster in plants of the cv. 'Ztota Saxa'. Both cultivars of bean showed also age-dependent resistance to infection by BYMV. All these viruses restricted growth and yield of plants. The decreases were greater when younger plants were inoculated. These dependences appeared most distinctly in pea cv. 'Sześciotygodniowy' infected with CMV and in two cultivars of bean infected with BYMV.
\end{abstract}

\section{INTRODUCTION}

It is usually assumed, both from the scientific and practical point of view, that young plants are particularly susceptible to pathogens, especially viruses. With growth and development of the plants this susceptibility gradually diminishes. This observation has been fully utilized among other circumstances in the production of seeding potatoes and in the production of yellow lupin for seed. It was found that the younger are the plants on which vector aphids of bean yellow mosaic virus feed the easier their infection takes place and the quicker virosis develops in the form of narrow, leaf of yellow lupin (B $\mathrm{l}$ a s z c z a k, 1963).

Investigations on this subject so important in plant production are aimed at elucidation, whether this is a general rule and whether such infection occurs in most leguminous plant species. The time of infection and rate of resistance increase with age are important in the ontogeny of the particular plant species. 
The present study was undertaken to investigate the susceptibility to viruses of pea, horse bean and bean in dependence on the age of the inoculated plants, and their reactions to infection.

\section{MATERIAL AND METHODS}

The experiments were performed in the glasshouse of the Department of Phytopathology, Agricultural University, Poznan in the years 1980 and 1981. Seeds of the plant species under study were received from the Plant Breeding Station Szelejewo and Wiatrowo*.

Pea (Pisum sativum L.) seeds cvs. 'Sześciotygodniowy' (veg. period 72-76 days), 'Kaliski' (110 days), 'Auralia' (113-114 days) and 'Paloma' (120-122 days), seeds of horse bean (Vicia faba subsp. minor Harz) cvs. 'Nad wiślański' and 'Major' and bean (Phaseolus vulgaris L.) cvs. 'Zlota Saxa' and 'Earle' were used in the experiments. The following viruses were applied: Cucumber Mosaic Virus (CMV) isolate PR7/77 isolated from tendril pea, Bean Yellow Mosaic Virus (BYMV) isolate P-251** and isolate R-20/75 from pea, Broad Bean True Mosaic Virus (BBTMV). The viruses in dried plant tissues were stored over calcium chloride and multiplied on tabacco (CMV), pea (BYMV) and horse bean (BBTMV). Ceramic pots 14 or $16 \mathrm{~cm}$ in diameter were used, filled with an equal amount of steamed field soil with compost soil added. Three experiments were carried out. In the first the starting moisture level was maintained at about 58 per cent of full water capacity and in the two remaining experiments the plants were uniformly watered when required. The seeds were planted directly into the pots in excess. After sprouting, weaker excess plants were removed and only a definite number was left for inoculation.

All experiments were performed in three replications. One replication consisted of one pot with 7-9 plants, exceptionally a different number of plants, if in the course of the experiment some plants died. For establishing the influence of the virus on seed yield each plant was examined separately. In the first experiment plants aged 16, 24, 38 and 52 days sown at four different dates were inoculated on the same day. In the second experiment plants aged 15,29 and 43 and in the third bean plants aged 17,31 and 45 days were inoculated. Two species of Trigonella aged 39, 50 and 61 days were additionally inoculated.

BYMV inocula were prepared routinely from infected pea plants, CMV from tobacco and BBTMV from horse bean after a lapse of about two weeks after inoculation. For dilution of BYMV and BBTMV water was used and in the case

*The authors thank both the Plant Breeding Stations for their help.

**Transmitted to us by Dr Cz. Kowalska from the Institute of Plant Genetics, Polish Academy of Sciences in Poznań - many thanks. 
of CMV phosphate-potassium buffer $0.01 \mathrm{M}, \mathrm{pH}$ 7. For each group of plants the same amount of inoculum was used. Plants dusted with carborundum were inoculated with viruses by means of a cheesecloth swab. The procedure of inoculation was as far as possible identical and comparable. After inoculation the plants were washed with water. For checking the quality and purity of the inocula, appropriate plant species were inoculated with them. In the course of observation the number of diseased plants was recorded. In doubtful cases back isolations were done. In several cases the noxious influence of viruses on plant growth was preliminarily determined, and the more interesting results, according to the authors, were statistically elaborated by analysis of variance for single classification.

The glasshouse was heated in the winter period. In summer it was shaded, aired and the floor was sprayed with water. The thermic and light conditions (in winter additional illumination with Polam LRFR $250 \mathrm{~W}$ lamps for 6 in $24 \mathrm{~h}$ ) varied widely. Mean monthly temperatures during the experiments in 1980 (March-June) varied from $14.3^{\circ}$ to $14.9^{\circ} \mathrm{C}$ and in 1981 in the 8 -month period (March-June and August-November) $14.0^{\circ}-19.4^{\circ} \mathrm{C}$ and $12.5^{\circ}-16.3^{\circ} \mathrm{C}$, respectively. These conditions ensured good growth of plants and development of viral diseases.

The glasshouse was kept free of insects virus vectors.

\section{RESULTS}

SUSCEPTIBILITY TO VIRUSES IN DEPENDENCE ON PLANT AGE AT INOCULATION

\section{Susceptibility of pea to CMV}

The three tested pea cultivars did not show differences under the experimental conditions (mean ten-day temperatures of environment within the range $13.3^{\circ}-17.3^{\circ} \mathrm{C}$ ) in susceptibility to $\mathrm{CMV}$ in dependence on the age of the inoculated plants. Only few plants were systemically infected, whereas the number of plants with local infection (Fig. 1) varied from 50.0 to 88.2 per cent (Table 1) and increased with the duration of the vegetation period of the given variety.

\section{Susceptibility of pea to BYMV}

It was noted that older plants were less susceptible to infection with BYMV than younger ones. Pea cv. 'Sześciotygodniowy' with a short vegetation period showed greatest differences in susceptibility. Plants inoculated at the age of 16 and 24 days proved fully susceptible (Table 2, Fig. 2), whereas the susceptibility of older plants was lower. In the second experiment the differences in susceptibility of this variety to BYMV were still wider (Table 3). In both experiments all the remaining pea cultivars with a longer vegetation period behaved similarly, only 


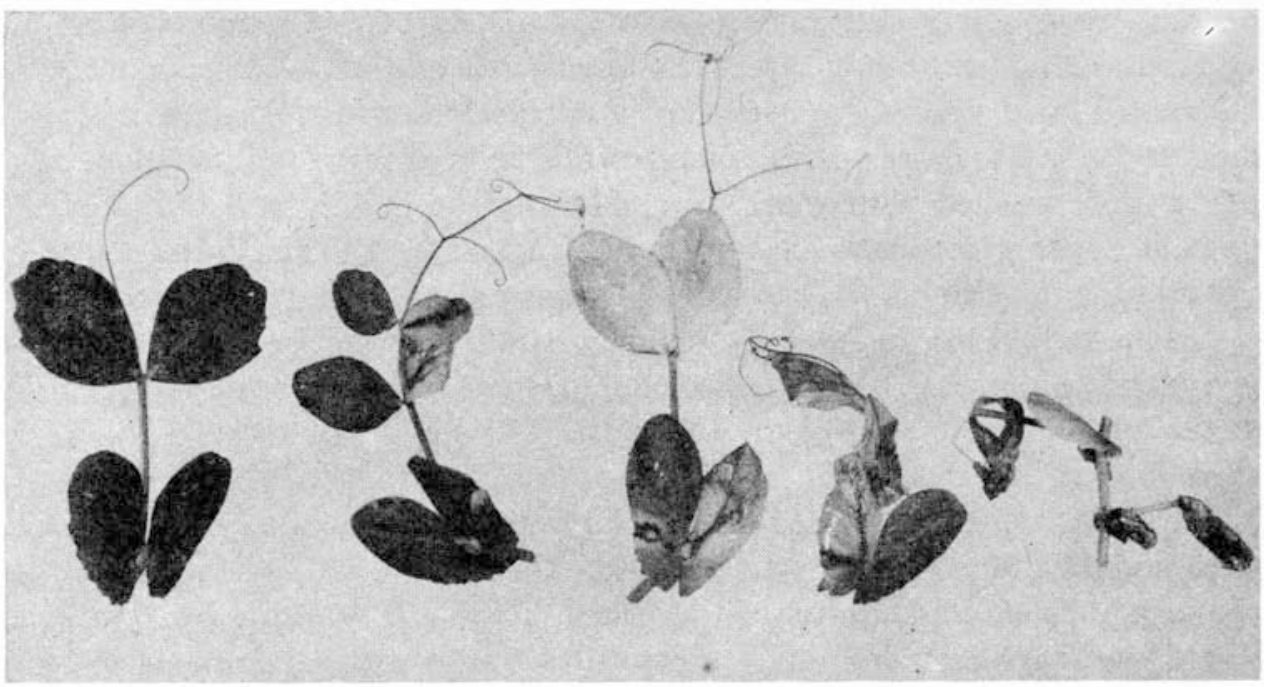

Fig. 1. Fragments of pea plants cv. 'Paloma'. On left of healthy plant, further of plants with local lesion caused by CMV, successively of plants from 1st to 4th sowing date

\section{T a b l e 1}

Susceptibility of three pea cultivars to CMV \% independently of age of inoculated plants*

\begin{tabular}{lclc}
\hline Cultivar & $\begin{array}{c}\text { Vegetation } \\
\text { period } \\
\text { days }\end{array}$ & $\begin{array}{c}\text { Kind of } \\
\text { infection }\end{array}$ & $\begin{array}{c}\text { Infected } \\
\text { plants } \\
\%\end{array}$ \\
\hline $\begin{array}{c}\text { Sześciotygod- } \\
\text { niowy' }\end{array}$ & $72-76$ & local & 50.0 \\
'Auralia' & $113-114$ & systemic & 17.3 \\
& & local & 70.5 \\
'Paloma' & $120-122$ & systemic & 5.7 \\
& & local & 88.2 \\
& & systemic & 6.9 \\
\hline
\end{tabular}

*Per 24 - 27 plants of each cultivar.

in the oldest plants (52,43 and 38 days) was there a slight reduction of sensitivity. Pea cv. 'Auralia' inoculated at the age of 52 days showed a distinct resistance connected with age (Table 2).

Susceptibility of horse bean to BYMV and BBTMV

No greater susceptibility to BYMV of plants of both horse bean (subsp. minor) cultivars was observed, when inoculated at the age of 15 days than in those 
Ta ble 2

Susceptibility of three pea cultivars to BYMV in dependence on the age of the inoculated plants

\begin{tabular}{|c|c|c|c|}
\hline \multirow{2}{*}{$\begin{array}{c}\text { Age of inocu- } \\
\text { lated plants } \\
\text { days }\end{array}$} & \multicolumn{3}{|c|}{ Systemically infected plants in cultivars, $\% *$} \\
\hline & $\begin{array}{l}\text { 'Sześcioty- } \\
\text { godniowy' }\end{array}$ & 'Auralia' & 'Paloma'** \\
\hline 52 & 65.4 & 30.8 & 88.9 \\
\hline 38 & 52.0 & 88.5 & 92.6 \\
\hline 24 & 100.0 & 96.1 & 100.0 \\
\hline 16 & 100.0 & 92.3 & 100.0 \\
\hline \multicolumn{4}{|c|}{$\begin{array}{l}\text { *Per } 25-27 \text { inoculated plants. } \\
\text { **Local symptoms were also noticeable. }\end{array}$} \\
\hline & $\mathrm{T}$ a & & \\
\hline \multicolumn{4}{|c|}{$\begin{array}{l}\text { Susceptibility of two pea cultivars to BYMV in dependence on age c } \\
\text { inoculated plants }\end{array}$} \\
\hline \multirow{2}{*}{\multicolumn{2}{|c|}{$\begin{array}{l}\text { Age of inoculated } \\
\text { plants days }\end{array}$}} & \multicolumn{2}{|c|}{ Systemically infected plants, $\%$} \\
\hline & & $\begin{array}{l}\text { cioty- } \\
\text { owy'* }\end{array}$ & 'Kaliski'** \\
\hline 43 & & 8.6 & 88.0 \\
\hline 29 & & 6.0 & 100.0 \\
\hline 15 & & 0.0 & 100.0 \\
\hline
\end{tabular}

*Per 21 - 26 inoculated plants.

**Per $25-34$ inoculated plants.

inoculated at the age of $\mathbf{4 3}$ days (Table 4). In general, notwithstanding the age of the inoculated plants, the cv. 'Major' was more susceptible. In two cases the differences were statistically significant. The resistance to BBTMV, on the other hand, was connected with age in both cultivars, but somewhat more pronounced in the cv. 'Major', the plants of which inoculated at the age of 15 and 29 days differed significantly from older plants inoculated at the age of 43 days.

\section{Susceptibility of bean to BYMV and BBTMV}

Plants of two bean cultivars 'Zlota Saxa' and 'Earle' showed a marked increase of resistance connected with age to infection with BYMV (Table 5). This resistance increased with age much faster and was more pronounced in plants of the cultivar 'Zlota Saxa' and somewhat less in the cultivar 'Earle' plants. The 


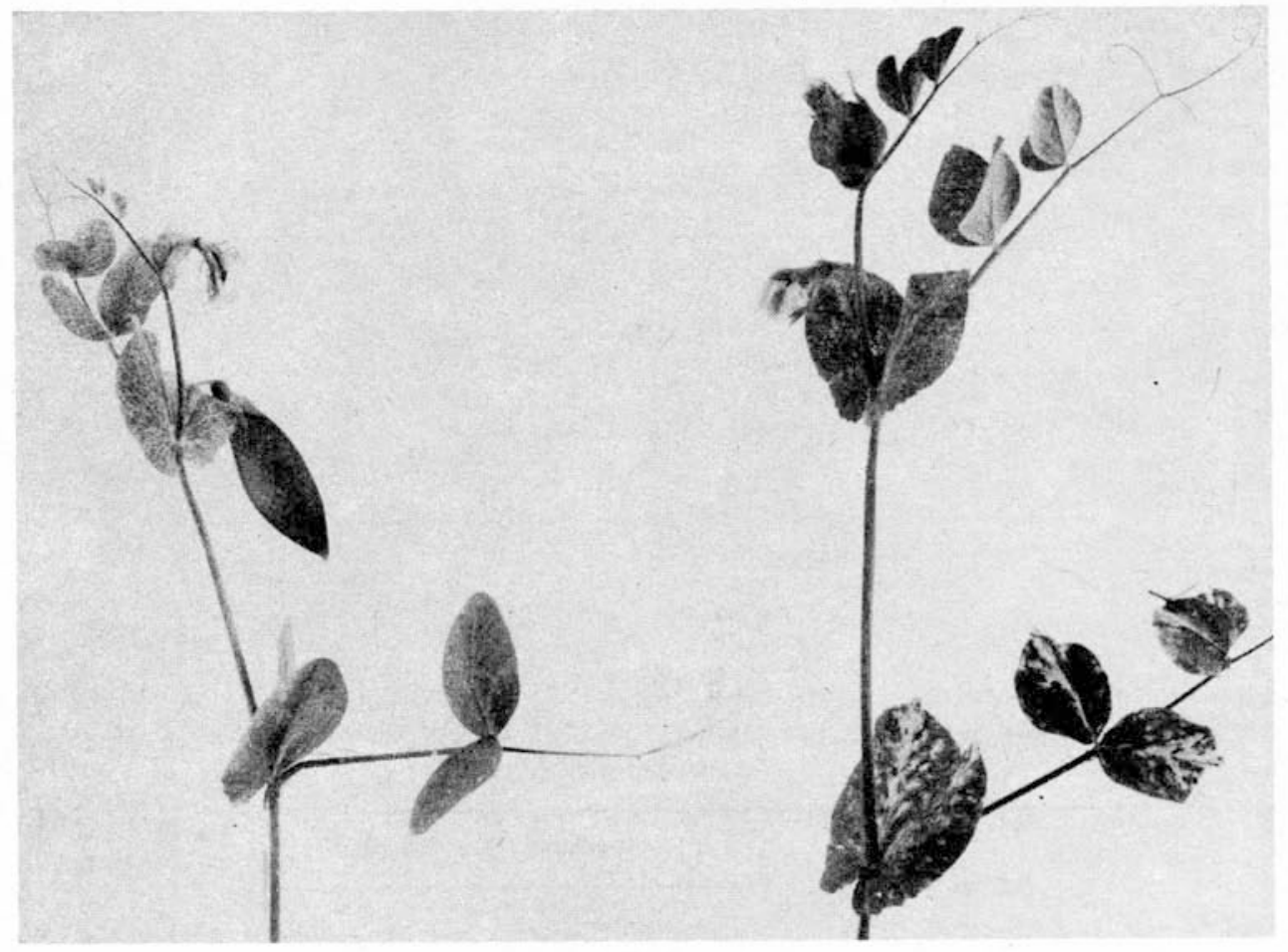

Fig. 2. Apexes of pea plants cv. 'Sześciotygodniowy' with symptoms of infection with BYMV - pea strain

T a b l e 4

Susceptibility of two horse bean cultivars to BYMV and BBTMV in dependence on age of inoculated plants

\begin{tabular}{cccc}
\hline \multirow{2}{*}{$\begin{array}{c}\text { Age of inocu- } \\
\text { lated plants } \\
\text { days }\end{array}$} & Viruses & \multicolumn{2}{c}{ Plants infected systemically, \%* } \\
\cline { 3 - 4 } & & 'Nadwiślański'** & 'Major*** \\
\hline 43 & BYMV & $66.7 \mathrm{f}$ & $93.0 \mathrm{e}$ \\
29 & $\#$ & $73.1 \mathrm{ef}$ & $100.0 \mathrm{e}$ \\
15 & $"$ & $66.7 \mathrm{f}$ & $90.9 \mathrm{e}$ \\
43 & BBTMV & $50.0 \mathrm{a}$ & $72.0 \mathrm{a}$ \\
29 & $"$ & $91.3 \mathrm{ab}$ & $95.8 \mathrm{~b}$ \\
15 & $"$ & $100.0 \mathrm{~b}$ & $90.5 \mathrm{~b}$ \\
\hline
\end{tabular}

*Per 18 - 26 inoculated plants.

**Values denoted by the same letter do not differ significantly at the level 0.05 . 
Ta b l e 5

Susceptibility of bean cultivares 'Zlota Saxa' and 'Earle' to BYMV in dependence on the age of the inoculated plants

\begin{tabular}{|c|c|c|c|c|c|c|}
\hline \multirow{4}{*}{$\begin{array}{c}\text { Age of } \\
\text { plants, } \\
\text { days }\end{array}$} & \multicolumn{3}{|c|}{ 'Ztota Saxa' } & \multicolumn{3}{|c|}{ 'Earle' } \\
\hline & \multicolumn{6}{|c|}{ number of plants } \\
\hline & \multirow{2}{*}{ inoculated } & \multicolumn{2}{|c|}{$\begin{array}{l}\text { systemically } \\
\text { infected }\end{array}$} & \multirow{2}{*}{ inoculated. } & \multicolumn{2}{|c|}{$\begin{array}{c}\text { systemically } \\
\text { infected }\end{array}$} \\
\hline & & $\begin{array}{c}\text { absolute } \\
\text { value* }\end{array}$ & $\%$ & & $\begin{array}{c}\text { absolute } \\
\text { value* }^{*}\end{array}$ & $\%$ \\
\hline 45 & 24 & $3 \mathrm{a}$ & 12.5 & 23 & $10 \mathrm{c}$ & 40.0 \\
\hline 31 & 22 & $8 \mathrm{ab}$ & 36.4 & 23 & $17 \mathrm{~d}$ & 73.9 \\
\hline $17^{\circ}$ & 24 & $23 \mathrm{~b}$ & 95.8 & 25 & $25 \mathrm{e}$ & 100.0 \\
\hline
\end{tabular}

*Values denoted in the column by the same letters a and b do not differ significantly at the 0.05 level, and those denoted by $c, d$, $e$ differ significantly at the 0.01 level.

Ta b l e 6

Susceptibility of bean cvs. 'Zlota Saxa' and 'Earle' to BBTMV, \%, in dependence on age of inoculated plants

\begin{tabular}{lcrr}
\hline & & \multicolumn{2}{c}{ Number/Percentage } \\
\cline { 3 - 4 } Cultivar & $\begin{array}{c}\text { Age of } \\
\text { plants } \\
\text { days }\end{array}$ & $\begin{array}{c}\text { plants } \\
\text { infected } \\
\text { locally* }\end{array}$ & $\begin{array}{c}\text { plants } \\
\text { infected } \\
\text { systemically* }\end{array}$ \\
\hline 'Zlota Saxa' & 45 & 1 no & infection \\
& 31 & $6^{* *} / 26.0$ & no \\
'Earle' & 17 & no & infection \\
& 45 & $1 / 4.3$ & $0 / 0$ \\
& 17 & $11 / 45.8$ & $7 / 29.2$ \\
\hline
\end{tabular}

*Per 24 inoculated plants.

**Per 23 inoculated plants.

number of infected plants after inoculation at the age of 45 days was 12.5 and 40.0 per cent, respectively. The two cultivars did not differ significantly from one another in the degree of resistance.

The greater susceptibility of the bean cultivar 'Earle' appeared also when BBTMV was applied (Table 6). Practically, only the youngest, 17-day plants were locally infected in the cultivar 'Zlota Saxa' in 26.0 per cent and in 'Earle' in 45.8 per cent. Systemic infection appeared only in plants of the cultivar 'Earle'. This 

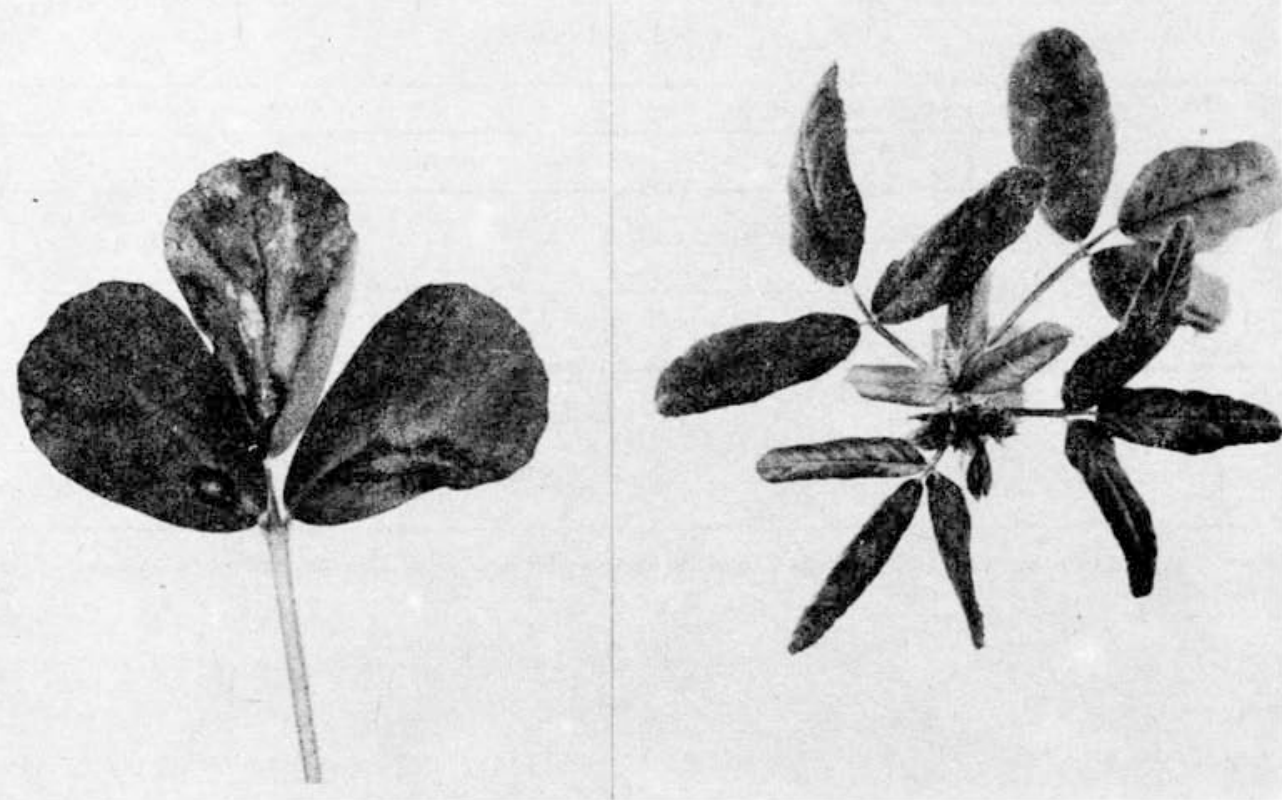

Fig. 3. Trigonella foenum graecum leaf with symptoms of local infection with CMV; on right - apex of T. coerulea systemically infected with BYMV

indicates that plants of the cultivar 'Zlota Saxa' were more and sooner resistant to BBTMV in connection with age than those of the cultivar 'Earle'.

Additionally plants of two species of Trigonella: T. coerulea (L.) Ser. and T. foenum graecum L. aged 39, 50 and 61 days were inoculated with CMV and BYMV. The former infected all plants locally and part of them systemically and the latter all plants locally and systemically (Fig. 3). Changes in susceptibility connected with age were not noted.

NOXIOUS EFFECT OF VIRUSES ON PEA AND BEAN

Influence of CMV on growth and yield of pea

CMV systemically infected but a small number of pea plants of the cv. 'Sześciotygodniowy', therefore, the data in Table 7 are only orientational. Nevertheless, they indicate a distinct dependence between the noxious effect of the disease and the age of the inoculated plants. All three indexes - the weight of the plant, the number and weight of seeds diminish with infection of decreasingly younger plants. For instance the weight of a plant infected at the age of 52 days decreased only by 5.5 per cent, whereas that of a plant infected at the age of 16 days was 55.0 per cent lower than the weight of healthy plants. 
T a b l e 7

Influence of CMV on growth and yield of pea cv. 'Sześciotygodniowy' in dependence on age of inoculated plants*

\begin{tabular}{cccc}
\hline $\begin{array}{c}\text { Age of } \\
\text { inoculated } \\
\text { plants } \\
\text { days }\end{array}$ & $\begin{array}{c}\overline{\mathrm{x}} \text { weight of } \\
\text { plants** }\end{array}$ & $\begin{array}{c}\overline{\mathrm{x}} \text { number of } \\
\text { seeds** }\end{array}$ & $\begin{array}{c}\overline{\mathrm{x}} \text { weight of } \\
\text { seeds** }\end{array}$ \\
\hline 52 & 94.5 & 81.4 & 61.5 \\
38 & 79.5 & 61.7 & 59.5 \\
24 & 56.9 & 59.8 & 42.5 \\
16 & 45.0 & 32.9 & 27.0 \\
\hline
\end{tabular}

* 18 diseased plants and 82 healthy plants were elaborated.

** Per cent of values for healthy plants.

Influence of BYMV on growth and yield of pea

The orientationally determined noxious effect of the disease in dependence on the age of the inoculated plant was rather distinct only in the pea cv. 'Sześciotygodniowy', whereas in the cultivars with a long vegetation period, 'Auralia' and 'Paloma' there was no pronounced dependence. Strange to say, the youngest plants of all three pea cultivars inoculated at the age of 16 days reacted weaker to infection with B YMV than older, 24-day ones (Fig. 4). In all three pea cultivars, notwithstanding their age, inoculation with BYMV reduced the seed yield to a higher degree than it did the yield of the plant weight (Table 8).

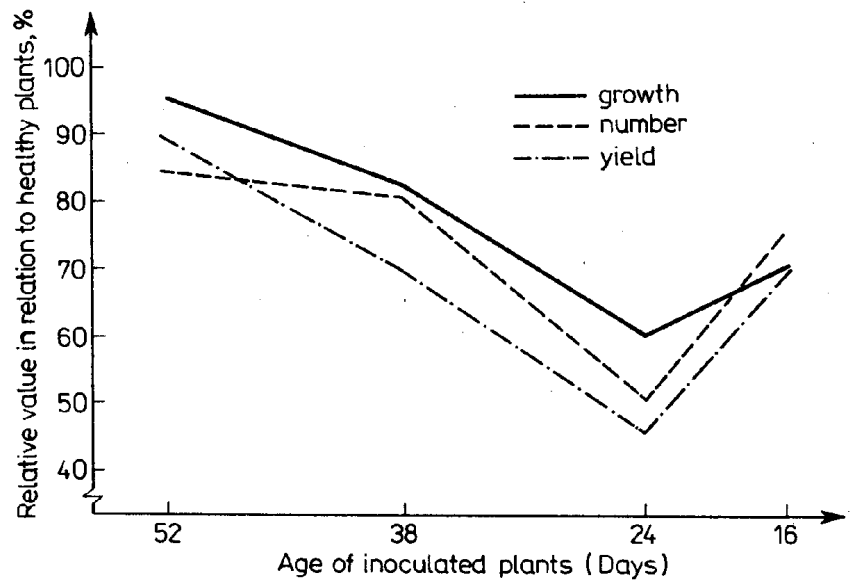

Fig. 4. Influence of BYMV on growth, number and yield of seeds of pea cv. 'Sześciotygodniowy' in dependence on age of inoculated plants 
T a b l e 8

- Influence of BYMV on weight (growth) of plants and seed yield of three pea cultivars, notwithstanding the age of the inoculated plants, given in relative values*

\begin{tabular}{lcccc}
\hline \multicolumn{1}{c}{ Features : } & Control & $\begin{array}{l}\text { 'Sześcioty- } \\
\text { godniowy' }\end{array}$ & 'Auralia' & 'Paloma' \\
\hline Weight of plants & 100 & 76.8 & 85.4 & 68.1 \\
Seed yield & 100 & 66.8 & 79.0 & 59.5 \\
\hline
\end{tabular}

*In relation to healthy plants.

Influence of BYMV on the weight of bean pods

Susceptibility of bean plants to infection with BYMV diminished similarly as older plants were infected and so did the noxious effect of the disease (Table 9). Bean plants of the cv. 'Zlota Saxa' infected at the age of 45 days gave a yield of pods only by 5.4 per cent lower (not significantly) than that of healthy plants. In younger plants inoculated at the age of 31 and 17 days the decrease in the pod weights was 32.1 and 54.5 per cent, respectively (Fig. 5). The bean cv. 'Earle' reacted somewhat stronger. Significant differences were found at the 0.05 level.

T a b l e 9

Influence of BYMV on yield of pods of two bean cultivars in dependence on age of inoculated plants

\begin{tabular}{|c|c|c|c|c|c|c|c|}
\hline \multirow[b]{2}{*}{$\begin{array}{l}\text { Age of } \\
\text { inocu- } \\
\text { lated } \\
\text { plants } \\
\text { days }\end{array}$} & \multirow[b]{2}{*}{ Plants } & \multicolumn{3}{|c|}{ cv. 'Earle' } & \multicolumn{3}{|c|}{ cv. 'Zlota Saxa' } \\
\hline & & $\begin{array}{l}\text { no. } \\
\text { of } \\
\text { elabo- } \\
\text { rated } \\
\text { plants }\end{array}$ & $\begin{array}{l}\text { weight } \\
\text { of pods } \\
\text { per } \\
\text { plant } \\
\text { g }\end{array}$ & $\begin{array}{c}\text { decrease } \\
\text { of } \\
\text { pod } \\
\text { weight } \\
\%\end{array}$ & $\begin{array}{l}\text { no. } \\
\text { of } \\
\text { elabo- } \\
\text { rated } \\
\text { plants }\end{array}$ & $\begin{array}{l}\text { weight } \\
\text { of pods } \\
\text { per } \\
\text { plant } \\
\text { g }\end{array}$ & $\begin{array}{c}\text { decrease } \\
\text { of } \\
\text { pod } \\
\text { weights } \\
\%\end{array}$ \\
\hline \multirow[t]{2}{*}{45} & healthy & 14 & 4.2 & - & 22 & 3.7 & \multirow{2}{*}{5.4} \\
\hline & diseased & 10 & 1 & not established & 3 & 3.5 & \\
\hline \multirow{2}{*}{31} & healthy & 21 & 2.6 & \multirow{2}{*}{50.0} & 23 & 2.8 & \multirow{2}{*}{32.1} \\
\hline & disceased & 17 & 1.3 & & 8 & 1.9 & \\
\hline \multirow{3}{*}{17} & healthy & 24 & 0.9 & \multirow{2}{*}{66.7} & 21 & 1.1 & \multirow{2}{*}{54.5} \\
\hline & diseased & 25 & 0.3 & & 23 & 0.5 & \\
\hline & LSD & & 0.5 & & & 0.6 & \\
\hline
\end{tabular}




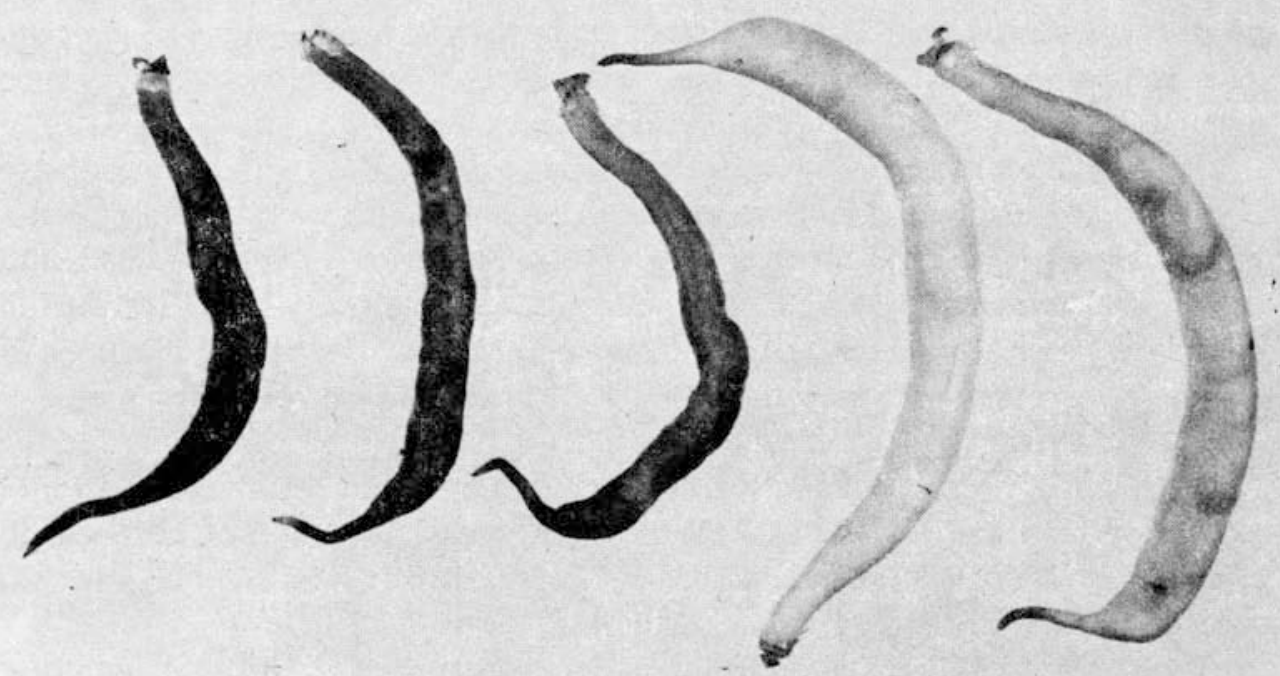

Fig. 5. Three pods of bean cv. 'Złota Saxa' from plants infected with BYMV. On right - two pods from healthy plants

\section{DISCUSSION}

The tested three pea cultivars, 'Sześciotygodniowy', 'Auralia' and 'Paloma' proved to be much more susceptible to BYMV than to CMV. In other experiments BYMV infected more than 80 per cent of the inoculated pea cv. 'Flawanda' plants whereas CMV infected only 10.8 per cent, of plants, of which almost half were infected only semisystemically .(B $¥$ a s z c z a k et al., 1984). On the other hand, pea cv. 'Lagiewnicki' was infected by BYMV almost completely $(99.1 \%$ ), and by CMV in 71.4 per cent (B ł a s z c z a k and $\mathrm{M} \mathrm{i} 1 \mathrm{c} \mathrm{h}$ e $\mathrm{r} \mathrm{t}$, 1980). This may indicate that the degree of infection depends on the pea cultivar, the virus and the environmental conditions. Most pea plants inoculated with CMV undergo local infection. Local necrotic spots form which, maybe, are the defence reaction of the plant.

No differences in susceptibility of pea to CMV with age of the inoculated plants were observed. More intensive local infection was only noted in the cultivars 'Auralia' and 'Paloma' with a longer vegetation period. In another experiment, however (B 1 a s z c z a k and G e m bi ck a-M or o z o w$\mathrm{s} \mathrm{k}$ a, 1984), resistance connected with age to infection with CMV was observed in the pea cv. 'Sześciotygodniowy' when the plants were inoculated at ages from 
16 to 53 days. When the youngest (1st) well developed leaf was inoculated older plants did not undergo infection. With decreasing age of the inoculated plants the number of infected ones increased, reaching in the youngest group 47.8 per cent. This finding was not noted when the third (older) leaf was inoculated. No such dependence was observed in cv. 'Auralia'.

Susceptibility of pea cultivars to BYMV also diminished with increasing age of the inoculated plants. This was most conspicuous in the cv. 'Sześciotygodniowy', and least in cultivars with a long vegetation period such as 'Kaliski' and 'Paloma' (Tables 2 and 3). Similar dependencies have already been described in an earlier paper, the percentage of infected plants, notwithstanding the inoculation time, increased with prolongation of the duration of the vegetation period of the given cultivar (B 1 a s z c z a k et al., 1984).

Both horse bean cultivars 'Nadwiślański' and 'Major' exhibited resistance connected with age to BBTMV (Table 4), whereas this was not observed in relation to. BYMV. The horse bean 'Nadwiślański' was significantly less susceptible to BYMV than the cv. 'Major'.

Both bean cultivars showed a distinct resistance to BYMV with age (Table 5).

The reaction of bean to BBTMV is very interesting. In the present experiments only the youngest plants of the cv. 'Zlota Saxa' were locally infected in 26 per cent, plants of the cv. 'Earle' proved much more susceptible (Table 6). In the experiments of B 1 a s z c z a k (1974) the bean cv. 'Zlota Saxa' at the phase of primary leaves development suffered from local and systemic infection, but it did not undergo infection at the phase of full development of primary leaves and developing trifoliate leaf. A similar reaction of bean is reported by $\mathrm{S} \mathrm{c} \mathrm{h}$ e i $\mathrm{n}$ (1965) in relation to Tobacco Mosaic Virus.

One may presume that the plant as environment of the virus changes in the course of ontogenetic development in a direction unfavourable for the virus, and that in why resistance connected with age appears. This phenomenon, however, may not take place in all species and cultivars of leguminous plants, and the time when resistance connected with age is manifested and the rate of its increase depend in a decisive degree on many features of the virus-plant system.

CMV and BYMV reduced both the weight and the yield of pea, the noxious effect of CMV being much more severe than that of BYMV (Tables 7,8). This is in agreement with the results of other investigations ( $\mathrm{Q}$ u a $\mathrm{ntz}, 1957$; $\mathrm{B} \nmid \mathrm{a} \mathrm{s} \mathrm{z} \mathrm{c} \mathrm{zak}$ and $\mathrm{M} \mathrm{i} \mathrm{l} \mathrm{c} \mathrm{hert,1980).} \mathrm{The} \mathrm{younger} \mathrm{were} \mathrm{the} \mathrm{inoculated}$ plants, the more injurious was the action of virosis (Table 6) which reduced most the seed yield and less their number and the weight of the plants, $K$ v i c a 1 a (1975) demonstrated a much more severe noxious effect of the Pea Enation Mosaic Virus (PEMV) when pea plants were inoculated at the 2-3 leaves stage than when this was done just before flowering. Błaszczak noted a marked 
dependence between the age of yellow lupin (Blaszczak, 1963) and horse bean plants (Błaszczak, 1970) infection with viruses and the influence of the latter on the seed yield. The same observation was made in the present study in the system bean - BYMV. Plants of both cultivars inoculated at the age of 17 days gave a pod yield by about 55-65 per cent lower than the control ones (Table 9). The decrease in the pod weight of the cv. 'Earle' the resistance of which in connection with age appeared later than in cv. 'Złota Saxa' was somewhat larger.

\section{CONCLUSIONS}

1. Nearly all the tested species and cultivars of leguminous plants (pea, horse bean, bean) show a certain degree of resistance connected with age to one or two of the viruses applied.

2. The time of appearance of resistance connected with age and the rate of increase of the latter depend on the relation virus-plant, and especially on the rate of changes occurring in the plant, that is the earliness of the cultivar.

3. The phenomenon of resistance connected with age has been and should be fully utilised in plant protection, in plant production (e.g. sowing dates) and also in various aspects of plant breeding.

\section{REFERENCES}

B ł a s z c z a k W., 1963. Badania nad wąskolistnością łubinu żółtego w warunkach Polski Zachodniej. Rocz. WSR Pozn. XV: 1-78.

B 1 a s z c z a k W., 1970. Influence of the time of inoculation of horse bean by the broad bean true mosaic virus (Vicia virus varians Quantz) on yield and seedtransmission of the virus. Zesz. Probl. Post. Nauk Rol. 111: 11-20.

B 1 a s z c z a k W., 1974. Patogeniczność, szkodliwość i niektóre inne właściwości wirusa właściwej mozaiki bobiku (Vicia virus varians Quantz). Rocz. Nauk Rol. 4: 121-137.

B ł a s z c z a k W., G e m bi c k a-M o r o z ow sk a M., 1984. Podatność dwóch odmian grochu na wirus mozaiki ogórka w zależności od wieku inokulowanych roślin i liści. Zesz. Probl. Post. Nauk Rol. 298: 29-38.

B ł a szczak W.; K a n i e wski W., Fi ed or ow Z., Miciński B., 1984. Podatność grochu na wirusy żółtej mozaiki fasoli i mozaiki ogórka a wiek roślin i kształtowanie się składu frakcji białk owych. Zesz. Probl. Post. Nauk Rol. 298: 13-27.

B 1 a s z c z a k W., M i $1 \mathrm{c} \mathrm{h}$ e r t M., 1980. Pea reaction to Cucumber Mosaic Virus and Bean Yellow Mosaic Virus in greenhouse conditions. Phytopath. Z. 99: 310-317.

K v i č a l a B. A., 1975. Vliv virus vyrustkove mozaiky hrachu na vynos hrachu sledovany w mikropokusu. Ochrana Rostlin. 11: 7-13.

Q u a n t z L., 1957. Über das Auftreten des Gurken Mosaikvirus auf Erbsen. Angew. Bot. 31: 166-173.

$\mathrm{S}$ q h e i n R. D., 1965. Age-correlated changes in susceptibility of Bean leaves to Uromyces phaseoli and Tobacco Mosaic Virus. Phytopath. 55- 454-457. 


\title{
Podatność grochu, bobiku i fasoli na wirusy w zależności od wieku inokulowanych roślin
}

\author{
Streszczenie
}

W doświadczeniach szk larniowych porównywano podatność grochu, bobiku i fasoli na wirusy w zależności od wieku roślin poddawanych zakażeniu. Trzy odmiany grochu - 'Sześciotygodniowy', 'Auralia' i 'Paloma' nie wykazały odporności związanej z wiekiem na CMV, natomiast różnice takie wystąpiły w stosunku do BYMV.

Odmiany bobiku 'Nadwiślański' i 'Major' wykazały wyraźną $\mathrm{i}$ istotną odporność związaną z wiekiem na BBTMV, ale nie na BYMV. Jednak podatność na BYMV bobiku odmiany 'Major' była ist otnie większa niż odmiany 'Nadwiślański'. Zmiana podatności na BYMV i BBTMV najwyraźniej wystąpiła w roślinach fasoli. Związana z wiekiem odporność na BYMV zwiększała się szybciej w roślinach fasoli odmiany 'Zlota Saxa'. Wyraźną odporność na BBTMV obserwowano u obydwu odmian fasoli, a szczególnie u odmiany 'Zlota Saxa', u której pojawiła się ona wcześniej i zwiększyła się szybciej niż u odmiany 'Earle'. Rośliny starsze 45-dniowe obydwu odmian nie podlegały porażeniu.

Wstępnie stwierdzono, że we wszystkich przypadkach stosowane wirusy spowodowały ograniczcnie wzrostu roślin i zmniejszaly plon nasion i strąków,'a obniżenia plonów były w zasadzie tym większe,im młodsze rośliny poddawano inokulacji. 